Doctor of law, colonel

Krasinsky Vladislav

\title{
THE TRANSFORMATION OF MODERN TERRORISM
}

Publication source: Krasinsky V.V. The transformation of modern terrorism // Modern Law. Number 2017. 9. P. 108-113.

In conditions of increasing military and political tensions in some regions of the world, exacerbation of ethnic and religious conflicts, the growth of social inequality, weakening and discredit of public institutions and the spread of radical ideological concepts we face the transformation of modern terrorism and the growing level of terrorist threats.

The highest level of terrorist threat is seen in a number of Middle East countries, North Africa and Central Asia.

In the Russian Federation, main terrorist threats are related to the activity of the armed underground in the North Caucasus, as well as the aspirations of the international terrorist organizations (hereinafter - ITO) to other regions of Russia. Aggressive propaganda activities carried out primarily through the Internet, allowing recruiters of ITO to involve in its activities of persons exposed to extremist ideologies. Actively and purposefully migrant background is used for radicalization of citizens of neighboring countries who were not able to adapt to our country. Such formation is called "sleeper cells" and "autonomous groups" for the subsequent commission of terrorist attacks. It represents a serious threat to the return of citizens who have received combat experience in the course of participation in armed conflict on the side of the ITO.

Thanks to an active terrorist and advocacy of ITO, the application of new tactical methods and means of terror in recent years, the following trends have become characteristic of modern terrorism: 
- Geographic expansion and internationalization of international terrorism, which is reflected in the large-scale expansion of the religious-extremist ideology and the formation of international on the composition of terrorist ${ }^{1}$ organizations.

-Improvement of the organization and methodical support of the leaders of ITO during the whole process. Modern organization of terrorist activities include the analysis and assessment of the situation, planning terrorist activities, recruitment, training, psychological treatment and equipment of performers, setting them tasks and also information and propaganda support of terrorist acts.

- Diversification of sources of funding and resource support for the ITO.

Today, the leadership of terrorist organizations is focused on achieving financial independence and the formation of its own sources of income, distributed in such a way as if one or more of them are overlapped it would not affect negatively on the $\mathrm{ITO}^{2}$ budget.

- Increased activity of independently operating terrorist cells and lone terrorists. Traditional group organization of terrorist activities successfully combined with "individual jihad" elements.

- Development of interregional and international relations between terrorist structures similar in its ideological and political orientation (especially between the structures set up at national-extremist and Islamic ${ }^{3}$ fundamentalist-based).

-Merging of terrorist thugs organized criminal communities.

This trend is evident in the organization of criminal groups controlled by thugs general criminal nature for the purpose of financing terrorist activities; the creation of bandit groups, fully staffed by persons who served sentence for the commission

${ }^{1}$ You can give an example of ITO "the ISIS". Thus, according to the US intelligence, in December 2014 on the territory of Syria and Iraq were at war for more than 18 thousand. Foreign fighters. By the end of 2015, their number has exceeded 25 thousand. People. from more than 100 countries worldwide. See. Final Report of the Task Force on September 2015. p.11.

2 Volodina N.V. The activity of the "Islamic State" ("the ISIS") as a threat to the constitutional security of Russia // Russian investigators. Number 2015. 3. P.45; Audrey Kurth Cronin. LIH - not a terrorist group // Russia in Global Affairs. Number 2015. 2. p. 148; 33. Merkuryev V.V. Agapov P.V. "Islamic State of Iraq and the Levant" (the ISIS) in the system of national security threats to Russia // Newsletter ATC. 2014. №23. p. 55-56.

${ }^{3}$ For details, see. Krasinsky V.V. Mashko V.V. International terrorist organization "Islamic State": Past, Present, and Future. M .: Infra-M, 2017. P. 63-65. 
of terrorist crimes; formation of the "prison", "Jamaat" in penal institutions, engaged in active religious-extremist convicted processing and collection of funds in the socalled "Beytumal" ( "treasury Muslims"); the use of members of paramilitary groups ties in the criminal environment for the acquisition of forged documents, weapons, explosives, drugs other items seized from civil circulation.

- Improving the information component of terrorist activity, the rapid development of terrorist organizations, advocacy infrastructure and use for illegal purposes of modern information and communication ${ }^{1}$ technologies.

Currently, in the global information network sites of almost all ITOs are operating. It can be told about a worldwide system of Internet resources of terrorist orientation. The major directions of terrorist activities on the Internet are: information support illegal actions of terrorist groups; liaising between the subjects of terrorist activities; the completion of the social base of terrorism; training and indoctrination of terrorists; fundraising.

Difficult situation along the line of counter-terrorism information is complicated by attempts of legitimizing terrorist leaders and ideologues from individual states. Thus, the United States and its allies are taking active attempts to substitute the concept of "counter-terrorism" the phrase "countering violent extremism." The main source of terrorist threats is "tyrannical rule of authoritarian regimes" that allows you to justify the activities of illegal armed groups (the socalled "moderate armed opposition") and initiate various scenarios of "colored revolutions" to destabilize "undesirable" political regimes.

System transformation of modern terrorism has a direct impact not only on the activity of the core of leadership, structural units and accessories of ITO, but also on the activities of intelligence and law enforcement agencies. It is mostly obvious on the example of the restructuring of operatively-search, criminal procedure, advocacy and operational and combat activities of law enforcement agencies, taking into account changes in terrorist tactics.

What is the tactics of modern terrorism, and what is its role?

${ }^{1}$ See. Krasinsky V.V. Protection of state sovereignty. M .: Norma, 2017. P. 84-85. 
The tactics of terrorist activities is a modus operandi of terrorist organizations (lone terrorists) in the solution of their problems in specific applications and environments.

Correctly chosen strategy allows terrorist organizations to systematically involve the vulnerable categories of citizens in terrorist activity, to make the resonant terrorist attacks, financial and resource to ensure its operational capacity, support the reproduction of supportive network, readiness and necessary reserve of conspiracy combat structural units. In turn, the knowledge and taking advantage of the tactical features of ITO's activity helps intelligence agencies and law enforcement agencies to organize opposition to the opponent:

- identify problem areas in the system of counter-terrorism security and critical infrastructure;

- identify vulnerable citizens in a recruiting plan and sympathizers of terrorist organizations of persons;

- carry out targeted activities under the information counteraction to terrorism and extremism;

- preparing to predict and prevent terrorist acts.

Each ITO has certain characteristics, which is connected with its management, structural construction, training fighters and technicians, resource provision, means the commission of terrorist crimes, the use of methods of conspiracy and money hiding terrorist activity.

You can demonstrate this on the example of the features of a terrorist "handwriting" one of the most capable, numerous and financial support of terrorist organizations - ITO "the Islamic State" ("the ISIS"1).

On the basis of the main areas of illegal aspirations of the MITO "the ISIS" tactics of activity of the "Islamic state" seems appropriate to analyze in the following building blocks:

1 The decision of the Supreme Court on December 29, 2014 number AKPI14-1424S international organization "the Islamic State" (also called "Islamic State of Iraq and Syria", "Islamic State of Iraq and the Levant", "Islamic State of Iraq and Sham") was recognized as a terrorist and banned its activities in the Russian Federation. 
- combat activities;

- terrorist activities;

- recruiting and ${ }^{1}$ outreach.

Active participation of the Russian Aerospace Forces in anti-terrorist operations in Syria, as well as the onset of the international coalition forces in Iraq have led to radical changes in the tactics of combat activity of the ISIS:

1. Militants began to disperse its forces and means, giving up their focus on open communication. They relocated their units from open terrain to the settlements are scattered heavy weapons and munitions.

2. The movement of troops and equipment has been carried out mostly at night, while during the day the militants prefer to travel in the desert areas outside the roads. They abandoned the large convoys became longer be used to move motorcycles and ${ }^{2}$ bicycles.

3. Militants started to use concealment measures that seriously hamper reconnaissance places militants dislocation more actively. For the purposes of disinformation members of the ISIS purposefully give to their positions civilian houses, hung out their flags over abandoned buildings, etc.

4. In spite of the presence of armored vehicles fighters try only, when absolutely necessary, to use heavy weapons, preferring mobility, so that "jihadists" are able as quickly and discreetly to concentrate their forces in areas of planned attacks.

The distinctive features of the ISIS remain well-organized intelligence and flexibility in the choice of tactics of the battle. Strong concentrated strikes militants combine multiple smaller raids, sabotage and terrorist acts, exhausting the opponent.

${ }^{1}$ See. Krasinsky V.V. Mashko V.V. International terrorist organization "Islamic State": Past, Present, and Future. M .: Infra-M, 2017. P. 33-49; Der, Islamische Staat '- Eine globaleelectronic resource] Access: https://www.verfassungsschutz.de/de/oeffentlichkeitsarbeit/presse/pm20160502-symposium-2016. Treatment Date: 23.05.2017.

${ }^{2}$ Slinkin M. Features warfare Syrian armed opposition // Russia and the Muslim world. 2016. № 12 (294). Р. 66. 
It should be noted that the unit commanders of militants scrutinized the plans of military operations, the preparation of which used intelligence obtained by visual observation, quadrocopter, as well as GPS-navigator and electronic maps of the area.

At uncontrolled or abandoned territories of the so-called "Islamic state" uses guerrilla tactics in an attempt to hold down force of government troops in Iraq and Syria.

A unique feature of modern terrorism is the desire ITO managers terrorist organizations to use their existing complex terrorist forces and resources to their optimum combination through complementary interlocking of terrorist acts.

Considering the ISIS's activities, it should be mentioned that the arsenal of methods used by this terrorist organization to commit terrorist acts is unlimited, but in most cases it is used by suicide bombers (as a rule, drivers of vehicles, ${ }^{1}$ bombs).

In order to intimidate and demoralize their opponents, the ISIS regularly conducts terrorist acts, as well as mass executions of captured soldiers and civilians hostage.

A new trend has been engaging in terrorist acts, as well as to the execution of the hostages the children (aged 12 years). At the same time they participate in executions, and as performers and as spectators.

It is spreading the concept of "autonomous" (individual) "jihad", which does not require the traditional tools of terror (Nice, Paris, Munich, London, and others.)).

Along with the militants householder with the emphasis is put on the mass formation of "sleeping" terrorist cells filled by trained terrorists, who have experience of warfare and committing crimes in the conflict zones.

During training at militant training camps (called "muaskars") recruits sets specific objectives for direct participation in the preparation and commission of terrorist acts after returning to the outcome of the regions. To this aim, they actively train mine explosives, clandestine work out communication channels. At the same time the awareness of these persons to hold against them operational and search

${ }^{1}$ The ISIS as a threat to international security. M .: RISR, 2015. P. 188 
activities and investigation leads to the fact that their return shall be subject to special measures of secrecy.

An important component of the ISIS tactics is recruiting and outreach.

Recruiting activity is the basis of maintaining the operational capacity, the high number of structural links and networks which support the "Islamic state".

Recruiting activities of ITO is accompanied by the popularization of extremist ideology and committing terrorist crimes.

It is related to the promotion of religious radicalism, the image of the glorification of his supporters, the idealization of "fair" public relations, the establishment of which seek terrorists and promises of wealth.

Active campaigning for travel in the "caliphate" is carried out by persons who are already taking part in the activities of the ISIS. The main focus of attention of recruiters is the youth.

When engaging in terrorist structure recruiters use psychological characteristics of persons recruited due to their immature outlook superficial knowledge of religious canons and dissatisfaction with the current government. During intercourse the main emphasis is on recruiter's glorification of warriors "jihad", extolling their military successes, the need to restore justice and protect the "true" followers of Islam from oppression.

In connection with the tangible losses of the ITO after Russia began the operation against terrorists in Syria and the advent of the coalition forces to the positions of the "Islamic state" in Iraq, the terrorists carry out search of spare bridgehead to carry their terrorist activity. Typical for the period of 2012-2015 mass agitation for travel in the "Caliphate" gave its way to intensify terrorist activities "on the ground".

Depending on the regions and countries recruiting activities the ISIS has its own specifics. In particular, in the countries of Southeast Asia advocacy the ISIS largely focused on the recruitment of young single students, young offenders and young people from families associated with the activities of radical religious 
organizations. Joining the ITO gives these categories of citizens' sense of belonging to the "great noble cause."

Currently the ISIS uses both active ways of involving citizens in its activities, in which its emissaries themselves determine potential candidates, carry out their checks and the subsequent psychological treatment (address effects) and methods of passive involvement when citizens sympathetic to terrorists trying to establish contacts with the ISIS on his own initiative as a result of its large-scale advocacy.

Global network is considered by the ISIS leaders as one of the main distribution channels of the control action to promote "jihad" ideas ${ }^{1}$.

Bright, regularly updated content of supporters of the ISIS on the Internet is the main motivating factor in generating interest in the activities of a terrorist organization by radical Muslims. Some of them seeks to proactively get in touch with the emissaries of the MTO or independently travels to Syria, where he joined the ranks of terrorist organizations.

Use of modern means of telecommunication allows recruiters and facilitators of the ISIS to pick up and learn new members to remotely control the actions of recruits, forming "dormant" cells over the Internet.

New trends of terrorism, changes in the tactics of illegal activity of the ISIS require timely flexible response, intelligence and law enforcement agencies.

Based on the identified trends of terrorism and the development of tactics of criminal activity of the ISIS perspective directions of further countering terrorist groups and "lone terrorists" are seen:

- identification and prevention of extremism among migrants;

- development and suppression of support bases and transit channels smuggled recruits and fighters increased terrorist activity in the area to participate in the combat actions on the side of the ISIS;

- suppression of logistical and financial support for the ISIS;

${ }^{1}$ Styshinsky $M$. jihadist propaganda on the Internet and social media // Political Linguistics. 2016. Vol. 5 (59). 
- poor coordination of terrorist activities, international and interregional relations between the WCO, terrorist cells and supportive networks;

- development and curbing the activities of organized criminal groups, ethnic groups affiliated with the businesses, organizations and business structures;

- active work on countering terrorist ideology in the social networks, the blogosphere, forums and data transmission services and Internet-pagers.

At present terrorism as a systemic phenomenon requires deep study and scientific understanding. A significant part in the field of counter-terrorism tasks should be solved with the mandatory involvement of interested institutions of civil society and the capacity of departmental science, designed to develop both theoretical and organizational-legal bases of the national antiterrorism system and extremism, as well as to develop measures timely response to the threat of terrorist and extremist nature. 